\title{
Cigarette smoking and the risk of diabetes in women.
}

\section{Citation}

Tonstad, Serena. 2009. 'Cigarette smoking, smoking cessation, and diabetes.' Diabetes Research and Clinical Practice 85, 1: 4-13. https://doi.org/10.1016/j.diabres.2009.04.013

\section{Permanent link}

http://nrs.harvard.edu/urn-3:HUL.InstRepos:41254612

\section{Terms of Use}

This article was downloaded from Harvard University's DASH repository, WARNING: This file should NOT have been available for downloading from Harvard University's DASH repository.

\section{Share Your Story}

The Harvard community has made this article openly available. Please share how this access benefits you. Submit a story.

\section{Accessibility}




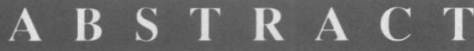

Objectives. Noninsulin-dependent diabetes mellitus, a major risk factor for cardiovascular disease, is prevalent in more than 12 million Americans. A voluminous amount of data demonstrates that cigarette smoking is an important cause of cancer and coronary heart disease. However, the association between cigarette smoking and the risk of diabetes is virtually unexplored, especially in women.

Methods. We examined the association between smoking and the incidence of noninsulin-dependent diabetes mellitus among 114247 female nurses who were free of diabetes, cardiovascular disease, and cancer in 1976. We collected exposure information and disease status prospectively for 12 years from biennially self-administered questionnaires.

Results. Current smokers had an increased risk of diabetes, and we observed a significant dose-response trend for higher risk among heavier smokers. During 1277589 personyears of follow-up, 2333 women were clinically diagnosed with diabetes. The relative risk of diabetes, adjusted for obesity and other risk factors, was 1.42 among women who smoked 25 or more cigarettes per day compared with nonsmokers.

Conclusions. These data suggest that cigarette smoking may be an independent, modifiable risk factor for noninsulin-dependent diabetes mellitus. (Am $J$ Public Health. $1993 ; 83: 211-214$ )

\section{Cigarette Smoking and the Risk of Diabetes in Women}

Eric B. Rimm, ScD, JoAnn E. Manson, MD, Meir J. Stampfer, MD, Graham A. Colditz, MBBS, Walter C. Willett, MD, Bernard Rosner, PhD, Charles H. Hennekens, MD, and Frank E. Speizer, MD

\section{Introduction}

Cigarette smoking decreases fasting insulin levels and causes a transient increase in blood glucose levels after an oral glucose challenge.1,2 Cigarette smoking is also associated with a greater waist-to-hip ratio, ${ }^{3,4}$ a measure of fat distribution that is related to diabetes. 5,6 However, the epidemiological data relating smoking to the development of diabetes are limited. In a 25-year prospective study among $841 \mathrm{mid}$ dle-aged Dutch men, ${ }^{7}$ controlled for age, subscapular skinfold, resting heart rate, alcohol, and energy intake, the relative risk (RR) of diabetes was 3.3 (95\% confidence interval $[\mathrm{CI}]=1.4,7.9$ ) among men smoking more than 20 cigarettes per day compared with never smokers. However, control for relative weight, family history of diabetes, and physical activity was not complete. In two other relatively small studies, no relation was seen between smoking and diabetes. ${ }^{8,9}$ To determine whether an association between smoking and noninsulin-dependent diabetes mellitus exists in women after controlling for known risk factors, we examined this relationship prospectively among 114247 participants in the Nurses' Health Study.

\section{Methods}

The Nurses' Health Study cohort was established in 1976 when 121700 female registered nurses, aged 30 to 55 years and living in 11 US states, returned a mailed questionnaire. Every 2 years, participants are mailed follow-up questionnaires to update information on cigarette smoking and other risk factors and to ascertain newly diagnosed diseases. In 1980 , we collected data on physical activity and alcohol consumption. ${ }^{10}$
Among the 121700 women originally enrolled in this study, 114247 were free from diabetes, coronary heart disease, and cancer in 1976. We mailed a supplementary questionnaire to women who reported a diagnosis of diabetes mellitus on any follow-up questionnaire. We defined cases of diabetes as being confirmed if one of the following conditions was reported on the supplementary questionnaire: (1) one or more classic symptoms (thirst, polyuria, weight loss, hunger, pruritus) plus an elevated fasting ( $\geq 140 \mathrm{mg} / \mathrm{dL}$ ) or random ( $\geq 200 \mathrm{mg} / \mathrm{dL}$ ) plasma glucose level; (2) on separate occasions, at least two elevated plasma glucose levels (fasting $\geq 140 \mathrm{mg} / \mathrm{dL}$ or random $\geq 200 \mathrm{mg} / \mathrm{dL}$, or $200 \mathrm{mg} / \mathrm{dL}$ after 2 hours or more on glucose tolerance testing) in the absence of symptoms; or (3) treatment with a hypoglycemic medication. We excluded 63 cases of insulin-dependent diabetes and 7 women with gestational diabetes only. Further details of the classification of diabetes can be found elsewhere. ${ }^{11,12}$

The validity of diabetes confirmation was documented with a random sample of participants reporting diabetes mellitus. Out of a sample of 84 women with con-

Eric B. Rimm, Meir J. Stampfer, Graham A. Colditz, Walter C. Willett, Bernard Rosner, and Frank E. Speizer are with the Harvard School of Public Health. JoAnn E. Manson, Charles H. Hennekens, and Drs. Colditz, Stampfer, Willett, Rosner, and Speizer are with the Channing Laboratory, Department of Medicine, Harvard Medical School and the Brigham and Women's Hospital, Boston, Mass.

Requests for reprints should be sent to Eric B. Rimm, Department of Epidemiology, Harvard School of Public Health, 677 Huntington Ave, Boston, MA 02115.

This paper was submitted to the Journal March 10, 1992, and accepted with revisions October 7, 1992. 
TABLE 1-Distribution of Characteristics among 114245 US Women, "According to 1976 Smoking Status

\begin{tabular}{|c|c|c|c|c|c|}
\hline & \multirow[b]{2}{*}{$\begin{array}{l}\text { Never } \\
\text { Smokers }\end{array}$} & \multirow[b]{2}{*}{ Ex-smokers } & \multicolumn{3}{|c|}{ Current Smokers } \\
\hline & & & $\begin{array}{l}1-14 \\
\text { Cig/Day }\end{array}$ & $\begin{array}{l}15-24 \\
\text { Cig:Day }\end{array}$ & $\begin{array}{l}25 \text { or More } \\
\text { Cig/Day }\end{array}$ \\
\hline Number & 49969 & 26602 & 10681 & 16533 & 10460 \\
\hline Mean age, y (SD) & $42.2(7.4)$ & $42.4(7.1)$ & $41.8(7.2)$ & $42.3(7.2)$ & $42.7(6.9)$ \\
\hline $\begin{array}{l}\text { Body mass index, } \\
\mathrm{kg} / \mathrm{m}^{2}(\mathrm{SD})\end{array}$ & $24.0(4.2)$ & $23.9(4.1)$ & $23.2(3.9)$ & $22.9(3.5)$ & $23.4(4.0)$ \\
\hline $\begin{array}{l}\text { Family history of } \\
\text { diabetes, \% }\end{array}$ & 16.9 & 16.8 & 14.7 & 14.6 & 15.0 \\
\hline $\begin{array}{l}\text { Alcohol use, }{ }^{\circ} \text { g/day } \\
\text { (SD) }\end{array}$ & $3.4(7.7)$ & $6.4(10.5)$ & $6.1(10.7)$ & $6.5(11.8)$ & $9.0(15.5)$ \\
\hline $\begin{array}{l}\text { Physical activity, } \\
\text { timesiweek, \% } \\
0 \\
1-3 \\
4+\end{array}$ & $\begin{array}{l}61.5 \\
24.0 \\
14.5\end{array}$ & $\begin{array}{l}61.2 \\
25.6 \\
13.2\end{array}$ & $\begin{array}{l}64.0 \\
24.9 \\
11.1\end{array}$ & $\begin{array}{r}69.2 \\
21.2 \\
9.6\end{array}$ & $\begin{array}{r}74.5 \\
17.5 \\
8.0\end{array}$ \\
\hline $\begin{array}{c}\text { Physician visits, }{ }^{\circ} \% \\
0 \\
1 \\
2+\end{array}$ & $\begin{array}{l}42.8 \\
20.9 \\
36.3\end{array}$ & $\begin{array}{l}41.1 \\
21.0 \\
37.9\end{array}$ & $\begin{array}{l}44.2 \\
21.4 \\
34.4\end{array}$ & $\begin{array}{l}45.1 \\
21.5 \\
33.4\end{array}$ & $\begin{array}{l}43.5 \\
20.5 \\
36.0\end{array}$ \\
\hline $\begin{array}{l}\text { aSample was of registe } \\
\text { and diabetes at basel } \\
\text { 'A family history of diab } \\
\text { the } 1982 \text { questionnair } \\
\text { 'Alcohol use was obtai } \\
\text { ¿Average number of we } \\
\text { a sweat (from the } 198 \\
\text { eNumber of physician }\end{array}$ & $\begin{array}{l}\text { red nurses, } \\
\text { ine. } \\
\text { etes is define } \\
\text { e). } \\
\text { ined from the } \\
\text { eekly episode } \\
30 \text { foliow-up q } \\
\text { visits during t? }\end{array}$ & $\begin{array}{l}30 \text { to } 55 \text { years o } \\
\text { ed as a mother, te } \\
1980 \text { questionn } \\
\text { es of physical act } \\
\text { questionnaire). } \\
\text { the previous yea }\end{array}$ & $\begin{array}{l}\text { lage and free } \\
\text { ther, sister, or } \\
\text { aire. } \\
\text { vity in which } \\
\text { (from the } 19\end{array}$ & $\begin{array}{l}\text { cardiovasct } \\
\text { se lasted lon } \\
\text { low-up ques }\end{array}$ & $\begin{array}{l}\text { disease, cancer } \\
\text { diabetes (from } \\
\text { hough to work up } \\
\text { naire). }\end{array}$ \\
\hline
\end{tabular}

firmed diabetes by supplementary questionnaire, 71 provided permission to obtain medical records and 62 of those $(87 \%)$ had medical records available. Upon review of these records, an endocrinologist (J. E. M.), blinded to information on the supplementary questionnaire, was able to confirm a diagnosis of diabetes in 61 of the 62 women (98.4\%).

Person-months of follow-up were accumulated for each risk factor, and risk factor status was updated every 2 years. For example, if a woman was smoking one pack of cigarettes per day in 1976, stopped in 1978, and was subsequently diagnosed with diabetes in 1984, she would contribute 2 years of person-time (1976 to 1978) to the 15 to 24 cigarettes-per-day category and 6 years of person-time (1978-1984) to the past smoking category. Because she was diagnosed with diabetes while being a past smoker, her diagnosis is counted in the incidence rate for past smokers, not current smokers. Women accumulated person-time of exposure until the date of diabetes, cancer, heart disease diagnosis, or death. Relative risks were calculated as the rate of disease among the exposed (total number of cases among smokers or past smokers divided by the total person-time of exposure) dinonexposed (total number of cases among nonsmokers divided by the total nonsmoking person-time). We calculated these risks by using the Mantel-Haenszel summary statistic to adjust for deciles of body mass index (kilograms/square meters) and 5-year age intervals. We also calculated $95 \%$ confidence intervals and, where applicable, Mantel extension tests ${ }^{13,14}$ for trend across increasing dosage levels among current smokers. Cox proportional hazard models were used to control simultaneously for potential confounders. ${ }^{15}$

\section{Results}

Average age did not differ materially among women who were never smokers, past smokers, or current smokers. However, smokers did have a lower body mass index, lower frequency of a family history of diabetes, higher alcohol consumption, and reduced physical activity (Table 1). The distribution of characteristics were similar among the nondiabetic population.

During 1277589 person-years of follow-up, we confirmed 2333 incident cases vided by the rate of disease among the of noninsulin-dependent diabetes mellitus. The age- and relative weight-adjusted relative risk of this disease among women smoking 25 or more cigarettes, compared with never smokers, was $1.37(95 \%$ CI $=1.16,1.62)$ (Table 2). The test for trend was also significant among smokers $(P$ trend $=.005)$, indicating a dose-response association between number of cigarettes smoked and risk of the disease.

We previously found moderate inverse associations between physical activity, ${ }^{11}$ specific nutrient intakes, ${ }^{16}$ alcohol consumption, ${ }^{17}$ and the risk of subsequent diabetes. Because information on diet, alcohol intake, and physical activity was first collected on the 1980 follow-up questionnaire, only incident cases after the return date of the 1980 questionnaire $(n=1578)$ were included in the multivariate models controlling for these and other risk factors (see Table 2). The multivariate relative risk of noninsulin-dependent diabetes mellitus among women smoking 25 or more cigarettes per day was $1.42(95 \%$ $\mathrm{CI}=1.18,1.72)$ compared with never smokers. The relative risk of the disease was intermediate among past smokers $(R R=1.10 ; 95 \% C I=1.00,1.20)$. Relative risk estimates for smokers versus nonsmokers were not appreciably altered when total energy, energy-adjusted vegetable fat, potassium, calcium, magnesium, or self-reported hypertension were added to the statistical model. In addition, the $40 \%$ increase in risk of the disease among women smoking 25 or more cigarettes per day compared with never smokers was not affected when newly diagnosed cases of noninsulin-dependent diabetes mellitus who also had incident coronary heart disease, cancer, or stroke diagnosed in the same 2-year time interval were excluded.

Bias may occur if smokers experience an increase in other adverse health effects that heighten physician surveillance for diabetes and other medical conditions. Smokers did not have a larger number of physician visits (Table 1), even after the number of visits among the diabetes-free population during the 12-year follow-up period was tabulated. To reduce the potential for bias further, we calculated relative risk estimates of noninsulin-dependent diabetes mellitus among smokers, using only incident symptomatic cases of diabetes $(n=1655)$ and adjusting for age and body mass index. The relative risk of the disease was $1.41(95 \% \mathrm{CI}=1.15,1.72)$ among women smoking 25 or more cigarettes per day compared with never smokers (Table 2). Furthermore, after taking alcohol consumption into account (data 


\begin{tabular}{|c|c|c|c|c|c|c|c|}
\hline & \multirow[b]{2}{*}{ Nonsmokers } & \multirow[b]{2}{*}{ Ex-smokers } & \multicolumn{4}{|c|}{ Current Smokers } & \multirow{2}{*}{$\begin{array}{l}P \\
\text { Trend }\end{array}$} \\
\hline & & & 1-14 Cig/Day & 15-24 Cig/Day & 25 or More & Cig/Day & \\
\hline Cases $^{C}$ & 1021 & 713 & 138 & 225 & & 201 & \\
\hline Person-years & 558957 & 350798 & 106404 & 156028 & 105 & 502 & \\
\hline $\begin{array}{l}\text { All cases } \\
\text { Age-adjusted relative risk } \\
(95 \% \mathrm{Cl})\end{array}$ & $\begin{array}{c}1.0 \\
\text { (Reference) }\end{array}$ & $(0.98,1.18)$ & $\begin{array}{r}0.73 \\
(0.61,0.88)\end{array}$ & $\begin{array}{r}0.82 \\
(0.71,0.94)\end{array}$ & 1.08 & $(0.92,1.25)$ & .001 \\
\hline $\begin{array}{l}\text { Age- and body mass } \\
\text { index-adjusted relative } \\
\text { risk }(95 \% \mathrm{Cl})\end{array}$ & (Reference) & $(1.02,1.25)$ & $\begin{array}{r}0.99 \\
(0.81,1.20)\end{array}$ & $(1.09,1.50)$ & 1.37 & $(1.16,1.62)$ & .005 \\
\hline $\begin{array}{l}\text { Multivariate relative risk } \\
(95 \% \mathrm{Cl})\end{array}$ & (Reference) & $(1.00,1.20)$ & $\begin{array}{r}0.95 \\
(0.76,1.20)\end{array}$ & $(0.99,1.43)$ & 1.42 & $(1.18,1.72)$ & .001 \\
\hline $\begin{array}{l}\text { Symptomatic cases only } \\
\text { Age-and body mass } \\
\text { index-adjusted relative } \\
\text { risk }(95 \% \mathrm{Cl})\end{array}$ & $\begin{array}{l}711 \\
\text { (Reterence) } \\
1.0\end{array}$ & $\begin{array}{c}519 \\
(1.06,1.35)\end{array}$ & $\begin{array}{r}87 \\
0.92 \\
(0.72,1.18)\end{array}$ & $\begin{array}{r}159 \\
1.37 \\
(1.14,1.66)\end{array}$ & 1.41 & $\begin{array}{l}148 \\
(1.15,1.72)\end{array}$ & .005 \\
\hline $\begin{array}{l}\text { Multivariate relative risk }{ }^{d} \\
(95 \% \text { Cl) }\end{array}$ & (Reference) & $(1.02,1.35)$ & $\begin{array}{r}0.90 \\
(0.68,1.19)\end{array}$ & $(0.96,1.50)$ & 1.49 & $(1.19,1.87)$ & .005 \\
\hline \multicolumn{8}{|c|}{ 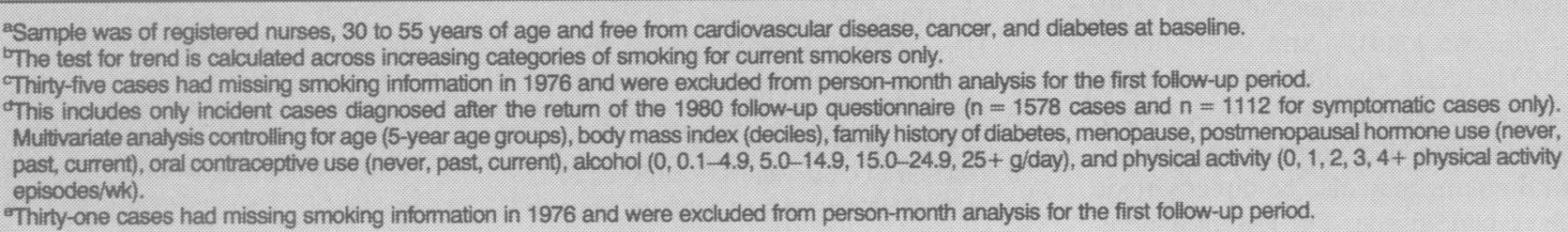 } \\
\hline
\end{tabular}

available only after June 1,1980 ), the multivariate relative risk was not appreciably different for the smaller subset of symptomatic cases $(n=1112)$ diagnosed after June 1, $1980(\mathrm{RR}=1.49 ; 95 \% \mathrm{CI}=1.19$, 1.87) (Table 2).

Obesity only slightly modified the association between smoking and diabetes. Among women with a body mass index not greater than $29.0 \mathrm{~kg} / \mathrm{m}^{2}$, the age- and obesity-adjusted relative risk of noninsulin-dependent diabetes mellitus was 1.23 (95\% CI $=0.87,1.74)$ for women smoking 25 or more cigarettes per day compared with never smokers (data not shown). Among women with a body mass index greater than $29.0 \mathrm{~kg} / \mathrm{m}^{2}$, the age- and obesity-adjusted relative risk of the disease was $1.40(95 \% \mathrm{CI}=1.11,1.75)$ for the same smoking level compared with never smokers.

\section{Discussion}

In these prospectively collected data, we observed a positive association between smoking and the risk of diabetes. The risk was more pronounced after we controlled for established predictors of the disease; it increased linearly with the num- ber of cigarettes smoked and was only slightly modified by obesity.

Because overall follow-up of this cohort involved more than $90 \%$ of original respondents, the results are unlikely to be biased by losses to follow-up. As many as $50 \%$ of diabetes cases are undiagnosed ${ }^{18}$; consequently, biased surveillance among smokers could theoretically inflate the diagnosis rate in these groups. However, because smoking is not related to the number of physician visits (Table 1), biased surveillance is unlikely to explain the elevated risk of diabetes among smokers. Furthermore, restricting the outcome to symptomatic cases of diabetes does not appreciably alter the magnitude of the association. Previously, we reported a strong association between relative weight and incident diabetes. ${ }^{19}$ Even after controlling for deciles of relative weight, residual confounding may exist among the top deciles where the increased relative risk of diabetes is more than 20 times that for women in the lowest decile. ${ }^{19}$ However, because smoking is inversely related to body mass index, ${ }^{20,21}$ residual confounding by relative weight, if anything, attenuates the association between smoking and diabetes. Therefore, our results may reflect an underestimate of the association between smoking and noninsulindependent diabetes mellitus.

In one other study, an association between smoking and diabetes was observed among men in the Zutphen study7; however, no association was seen in two others. ${ }^{8,9}$ Feskens and Kromhout ${ }^{7}$ followed 841 middle-aged men for 25 years and documented 58 new cases of diabetes. After they controlled for age, subscapular skinfold, resting heart rate, alcohol, and energy intake, the relative risk of developing diabetes was $3.3(95 \% \mathrm{CI}=1.4,7.9)$ among men smoking 20 cigarettes per day compared with nonsmokers. Wilson et al. ${ }^{9}$ followed 1320 women for 8 years in the Framingham Heart Study and found that, among the 38 new cases of diabetes, the baseline rate of smoking did not differ from that in the reference population of nondiabetics after controlling for age, body mass index, lipoprotein profile, blood pressure, and diuretic use. Similarly, in a 5-year follow-up of 8688 men in the Israeli Ischemic Heart Disease Project, Medalie et al. ${ }^{8}$ reported no increased risk of diabetes among current smokers as compared with nonsmokers after controlling for age, body mass index, peripheral 
vascular disease, cholesterol, blood pressure, uric acid, hemoglobin, country of birth, and educational status. Previous studies have been small and have controlled for only three or four obesity categories and not for family history of diabetes, physical activity, and alcohol intake (except for the Zutphen study). ${ }^{7}$ Therefore, the association between smoking and diabetes in these studies may have been missed.

Although smoking is generally inversely associated with body mass index, Shimokata et al. ${ }^{3}$ reported an increase in the waist-to-hip ratio among men who started smoking; this increase was noted despite the subjects' weight loss. Among women, smoking may have an "antiestrogenic" effect, causing adverse changes in the waist-to-hip ratio. $3,22,23 \mathrm{An}$ increased waist-to-hip ratio, a marker of the ratio of intra-abdominal to subcutaneous fat, has been shown to be significantly positively correlated with insulin resistance, ${ }^{24}$ plasma glucose levels (after oral glucose load), ${ }^{25}$ and overt diabetes.5,6 Therefore, the effect of smoking on the development of diabetes may be mediated through alterations in fat distribution. Smoking may also be directly toxic to pancreatic tissue. The risk of pancreatic cancer is elevated among smokers $^{26,27}$ and the diabetic population. ${ }^{27,28}$ Thus, biological mechanisms that explain the association between smoking and diabetes may also play a role in development of pancreatic cancer. Further investigation of the interrelationships between smoking, relative weight, and fat distribution and the subsequent development of diabetes is needed to help clarify these mechanisms.

In conclusion, after controlling for known predictors of diabetes, we found a moderate association between smoking and the subsequent risk of diabetes. Our findings from this large prospective cohort of women provide new evidence that cigarette smoking may be a modifiable risk factor that could be targeted for diabetes prevention.

\section{Acknowledgments}

This study was supported by research grants DK36798 and CA40356 from the National Institutes of Health. Eric Rimm was supported by a National Institute of National Research Service Award 5T32 CA09001.

The authors thank the participants of the Nurses' Health Study for their continued cooperation and participation. The authors are also indebted to Mark Shneyder, Karen Corsano, Gary Chase, Maureen Ireland, and Steven Stuart for their expert and unfailing assistance.

\section{References}

1. Janzon L, Berntorp $K$, Hanson M, Lindell SE, Trell E. Glucose tolerance and smoking: a population study of oral and intravenous glucose tolerance test in middle-aged men. Diabetologia. 1983;25:86-88.

2. Grunberg NE, Popp KA, Bowen DJ, et al. Effects of chronic nicotine administration on insulin, glucose, epinephrine, and norepinephrine. Life Sci. 1988;42:161-170.

3. Shimokata H, Muller DC, Andres R. Studies in the distribution of body fat: III. effect of cigarette smoking. JAMA. 1989;261: 1169-1173.

4. Seidell JC, Cigolini M, Deslypere JP, Charzewska J, Ellsinger B, Cruz A. Body fat distribution in relation to physical activity and smoking habits in 38-year-old European men. Am J Epidemiol. 1991;133: 257-265.

5. Hartz AJ, Rupley DC, Rimm AA. The association of girth measurements with disease in 32856 women. Am J Epidemiol. 1984;119:71-80.

6. Ohlsson LO, Larsson B, Svärdsudd K, et al. The influence of body fat distribution on the incidence of diabetes mellitus: 13.5 years of follow-up of the participants in the study of men born in 1913. Diabetes. 1985; 34:1055-1058.

7. Feskens EJ, Kromhout D. Cardiovascular risk factors and the 25-years incidence of diabetes mellitus in middle-aged men. Am J Epidemiol. 1989;130:1101-1108.

8. Medalie JH, Papie CM, Goldbourt U, Herman JB. Major factors in the development of diabetes mellitus in 10000 men. Arch Intern Med. 1975;135:811-817.

9. Wilson PWF, Anderson KM, Kannel WB. Epidemiology of diabetes mellitus in the elderly. Am J Med. 1986;80(Suppl 5A): 3-9.

10. Giovannucci E, Colditz GA, Stampfer MJ, et al. The assessment of alcohol consumption by a simple self-administered questionnaire. Am J Epidemiol. 1991;133: 810-817.

11. Manson JE, Rimm EB, Stampfer MJ, et al. Physical activity and incidence of noninsulin-dependent diabetes mellitus in women. Lancet. 1991;338:774-778.

12. Manson JE, Rimm EB, Stampfer MJ, et al. Post-menopausal hormones and diabetes mellitus. Ann Epidemiol 1992;2:665-673.

13. Mantel N. Chi-square tests with one degree of freedom: extensions of the MantelHaenszel procedure. J Am Stat Assoc.
1963;58:690-700.

14. Rothman KJ, Boice JD Jr. Epidemiologic Analysis with a Programmable Calculator. Washington, DC: Public Health Service; 1979. NIH publication 79-1649.

15. Cox DR. Regression models and life-tables. J R Stat Soc [B]. 1972;34:187-220.

16. Colditz GA, Manson JE, Stampfer MJ, et al. Diet and risk of clinical diabetes in women. Am J Clin Nutr. 1992;55:10181023.

17. Stampfer MJ, Colditz GA, Willett WC, et al. A prospective study of moderate alcohol drinking and risk of diabetes in women. Am J Epidemiol. 1988;128:549-558.

18. Harris MI. Prevalence of noninsulindependent diabetes and impaired glucose tolerance. In: National Diabetes Data Group, eds. Diabetes in America: Diabetes Data Compiled 1984. Washington, DC: National Institutes of Health; 1985:VI 1-31.32. DHHS publication PHS 85-1468.

19. Colditz GA, Willett WC, Stampfer MJ, et al. Weight as a risk factor for clinical diabetes in women. Am J Epidemiol 1990; 132:510-513.

20. Albanes D, Jones DY, Micozzi MS, Mattson ME. Associations between smoking and body weight in the US population: analysis of NHANES II. Am J Public Health. 1987;77:439-444.

21. Grunberg NE. The inverse relationship between tobacco use and body weight. In: Kozlowski LT, Annis HM, Cappell HD, et al., eds. Research Advances in Alcohol and Drug Problems. New York, NY: Plenum Press; 1990:273-315.

22. Friedman AJ, Ravnikar VA, Barbieri RL. Serum steroid hormone profiles in postmenopausal smokers and nonsmokers. Fertil Steril. 1987;47:398-401.

23. Khaw KT, Tazuke S, Barret-Connor E. Cigarette smoking and level of adrenal androgens in post-menopausal women. $N$ Engl J Med. 1988;318:1705-1709.

24. Krotkiewski M, Björntorp P, Sjöström L, Smith U. Impact of obesity on metabolism in men and women: importance of regional adipose tissue distribution. $J$ Clin Invest. 1983;72:1150-1162.

25. Sparrow D, Borkan GA, Gerzof SG, Wisniewski C, Silbert CK. Relationship of fat distribution to glucose tolerance: results of computed tomography in male participants of the normative aging study. Diabetes. 1986;35:411-415.

26. MacMahon B. Risk factors for cancer of the pancreas. Cancer. 1982;50:26762680.

27. Cuznick J, Babiker AG. Pancreatic cancer, alcohol, diabetes mellitus and gall-bladder disease. Int J Cancer. 1989;43:415-421.

28. Whittemore AS, Paffenbarger RS, Anderson $\mathrm{K}$, Halperin $\mathrm{JH}$. Early precursors of pancreatic cancer in college men.J Chron Dis. 1983;36:251-256. 